\title{
Pengaruh berbagai formulasi pengencer dasar air kelapa terhadap kualitas semen cair sapi PO (Peranakan Ongole) selama simpan dingin
}

\section{Effect of various formulations of coconut water on the quality of PO (Ongole Peranakan) bull sperm during cold storage}

\author{
Dedi Muhammad $^{1)}$, Nurul Isnaini ${ }^{1)}$, Kuswati ${ }^{1)}$, Aulia Puspita Anugra Yekti ${ }^{1)}$, Aryogi $^{2)}$, \\ Muhammad Lutfi ${ }^{2)}$, H.Y. Lukman ${ }^{2)}$, Trinil Susilawati ${ }^{1) *}$ \\ 1) Fakultas Peternakan Universitas Brawijaya Malang \\ 2) Loka Penelitian Sapi Potong Grati, Pasuruan
}

Submitted: 27 September 2018, Accepted: 26 Januari 2019

\begin{abstract}
ABSTRAK: Pengencer dasar air kelapa merupakan solusi dari sulit dan mahalnya harga pengadaan bahan baku pembuatan pengencer. Tujuan dari penelitian ini adalah untuk mengetahui pengaruh penggunaan berbagai formulasi pengencer dasar air kelapa terhadap kualitas semen cair sapi PO selama simpan dingin pada suhu $2-5^{\circ} \mathrm{C}$. Penelitian dilakukan di Laboratorium Reproduksi Ternak Fakultas Peternakan Universitas Brawijaya dan Laboratorium Loka Penelitian Sapi Potong Grati Pasuruan, pada bulan Maret hingga April 2018. Metodologi yang digunakan adalah percoboaan menggunakan rancangan acak kelompok (RAK). Penelitihan ini menggunakan 4 perlakukan, yaitu $\mathrm{P} 0=$ Pengencer CEP-3 $+20 \%$ kuning telur, P1 = Pengencer air kelapa $+20 \%$ kuning telur, $\mathrm{P} 2=$ Pengencer air kelapa $+20 \%$ kuning telur $+0,4 \%$ putih telur + fruktosa $1 \mathrm{mg} / \mathrm{ml}$. P3 $=$ Pengencer air kelapa $+20 \%$ kuning telur $+0,4 \%$ putih telur + fruktosa $2 \mathrm{mg} / \mathrm{ml}$ dengan 10 ulangan. Hasil menunjukkan bahwa terdapat perbedaan yang signifikan pada motilitas spermatozoa antara pengencer CEP-3 (P0) dengan pengencer berbasis air kelapa (P1, P2, P3) selama peyimpana suhu $2-5{ }^{\circ} \mathrm{C}$. Namun antar perlakuan pada pengencer berbasis air kelapa (P1, P2, P3) tidak menunjukkan perbedaan yang signifikan. Pengencer berbasis air kelapa mampu mempertahankan motilitas spermatozoa hingga hari ke 5 dengan nilai diatas $57 \%$.
\end{abstract}

Kata kunci : air kelapa; kapasitasi; motilitas; reaksi akrosom.

ABSTRACT: Coconut water extender is the solution to the difficulty and high cots of procurement of diluents. The objective of this study was to examine the effect of various formulations of coconut water extender on quality of PO bull sperm during storage in $4-5^{\circ} \mathrm{C}$. This study was carried out at Animal Reproduction Laboratory of Faculty of Animal Husbandry Brawijaya University and Laboratory of Beef Cattle Research Center Grati Pasuruan on March to April, 2018. The study method used laboratory experimental. The experimental design was Factorial Randomized Completely Block Design and the data were analyzed by Analyze of Variance. There are four treatments in this study $(\mathrm{P} 0=\mathrm{CEP}-3+$ $20 \%$ of yolk, $\mathrm{P} 1=$ Coconut Water $+20 \%$ of yolk, $\mathrm{P} 2=$ Coconut Water $+20 \%$ of yolk $+0,4 \%$ white egg + fructose $1 \mathrm{mg} / \mathrm{ml}$, dan $\mathrm{P} 3=$ Coconut Water $+20 \%$ of yolk $+0,4 \%$ white egg + fructose 2 $\mathrm{mg} / \mathrm{ml}$ ) and ten replications of each treatment. There were significant differences in sperm motility between CEP-3 extender and coconut water-based with various formula extenders during chilled storage at $2-5{ }^{\circ} \mathrm{C}$. But the treatment between coconut water-based formulas did not show a significant difference. Coconut water extenders are able to maintain sperm motility up to day 5 with values above $57 \%$.

Keywords : acrosom reaction; capacitation; coconut water; motility.

*Corresponding Author: trinil_susilawati@yahoo.com 


\section{PENDAHULUAN}

Semen cair merupakan semen yang telah ditambahkan dengan pengencer kemudian disimpan pada suhu $2-4{ }^{\circ} \mathrm{C}$ (Susilawati dkk., 2018). Penambahan bahan pengencer bertujuan untuk memenuhi kebutuhan nutrisi serta menyediakan lingkungan yang sesuai bagi spermatozoa. Selain itu pengencer juga harus mampu melindungi spermatozoa dari kerusakan akibat suhu, dan dibuat dari bahan yang tidak mahal serta ketersediaanya mudah didapatkan (Susilawati, 2011).

Air kelapa dapat dijadikan sebagai pengencer alternatif yang mudah didapatkan karena banyak tersedia di lingkungan sekitar dan harganya terjangkau. Beberapa karbohidrat sederhana, mineral dan zat-zat lain dalam pengencer yang diperlukan oleh spermatozoa dapat dipenuhi dari air kelapa. Menurut Vigliar, Sdepanian, and Neto (2006) air kelapa mengandung unsur karbon berupa karbohidrat sederhana, seperti: glukosa, sukrosa, dan fruktosa.

Hasil penelitian Mugiyati dkk. (2017) menunjukkan bahwa penggunaan pengencer air kelapa merah mampu mempertahankan motilitas spermatozoa kambing boer di atas $40 \%$ hingga hari ke-2 selama penyimpanan pada suhu dingin. Demikian pula dengan hasil penelitian Audia dkk. (2017) bahwa penggunaan pengecer air kelapa hijau mampu mempertahankan motilitas spermatozoa kambing boer di atas $40 \%$ hingga penyimpanan hari ke-2 selama penyimpanan pada suhu $3-5^{\circ} \mathrm{C}$.

Proses pengenceran semen dapat menimbulkan turunnya konsentrasi zat-zat yang terkandung dalam plasma semen seperti kadar asam amino, dan ion-ion yang dapat merubah keseimbangan tekanan osmose pada pengencer yang dapat mempengaruhi motilitas dan daya hidup (Adnani, Bebas, dan Budiasa, 2012). Penambahan sumber energi berupa fruktosa dan penambahan zat makromolekul berupa protein eksogenus dalam pengencer air kelapa diharapkan dapat mensubstitusi beberapa zat yang hilang dari plasma semen akibat proses pengenceran sehingga dapat menunjang kehidupan spermatozoa.

Pengencer berbahan dasar air kelapa dengan suplementasi kuning telur sebagai krioprotektan, fruktosa sebagai sumber energi tambahan dan putih telur sebagai makromolekul diharapkan dapat mempertahankan kualitas spermatozoa seoptimal mungkin. Berdasarkan uraian tersebut perlu dilakukan penelitian tentang pengaruh berbagai formulasi pengencer dasar air kelapa terhadap kualitas semen cair sapi PO selama simpan dingin.

\section{MATERI DAN METODE \\ Lokasi dan waktu penelitian}

Penelitian dilaksanakan di Laboratorium Loka Penetilian Sapi Potong Grati Pasuruan dan Laboratorium Reproduksi Ternak Fakultas Peternakan Universitas Brawijaya pada bulan Maret - April 2018.

\section{Semen sapi PO}

Semen yang digunakan yaitu semen yang berasal dari sapi PO yang dipelihara di Loka Penetilian Sapi Potong Grati Pasuruan dengan kriteria motilitas massa $\geq$ $2+$, motilitas individu $\geq 70 \%$. Frekuensi penampungan dua kali per minggu. Semen ditampung menggunakan metode vagina buatan.

\section{Pengencer air kelapa}

Air kelapa diambil dari buah kelapa hijau (Cocos nucifera) dengan usia 5-8 bulan. Sebelum digunakan terlebih dahulu disaring dengan kertas saring halus kemudian dipanaskan pada suhu $56{ }^{\circ} \mathrm{C}$ selama 20 menit untuk menonaktifkan enzim yang ada pada air kelapa. Kemudian ditambahkan kuning telur ayam 20\%, NaHCO3 $1 \mathrm{mg} / \mathrm{ml}$, antibiotik penicillin 1 $\mathrm{mg} / \mathrm{ml}$, streptomycin sulfate $1 \mathrm{mg} / \mathrm{ml}$, dan 
sebagai perlakuan yaitu putih telur ayam $0,4 \%$, fruktosa 10 dan $20 \mathrm{mg} / \mathrm{ml}$.

\section{Pengencer CEP-3}

Bahan pengencer CEP-3 terdiri dari $\mathrm{NaCl} 0,88 \mathrm{gr} / \mathrm{l} ; \mathrm{KCl} 0,52 \mathrm{gr} / \mathrm{l} ; \mathrm{CaCl}_{2}\left(\mathrm{H}_{2} \mathrm{O}\right)_{2}$ $0,44 \mathrm{~g} / \mathrm{l} ; \mathrm{MgCl}_{2}\left(\mathrm{H}_{2} \mathrm{O}\right)_{6} 0,81 \mathrm{~g} / \mathrm{l} ; \mathrm{NaHCO}_{3} 1$ $\mathrm{g} / \mathrm{l} ; \mathrm{NaH}_{2} \mathrm{PO}_{4} 0,96 \mathrm{~g} / \mathrm{l} ; \mathrm{KH}_{2} \mathrm{PO}_{4} 2,72 \mathrm{~g} / \mathrm{l}$; Fruktosa 9,9 g/l; Sorbitol $1 \mathrm{~g} / \mathrm{l}$; Tris Aminomethan 16,19 g/l; Gentamicin 0,05 g/l; Asam Sitrat 8,24 g/l. Bahan-bahan dicampur hingga menghasilkan osmolaritas 320 mOsm dan $\mathrm{pH}$ 6,6. Pengencer CEP-3 ditambahkan kuning telur segar (umur $<3$ hari) dengan $20 \%$ dan putih telur $0,4 \%$.

\section{Rancangan penelitian}

Rancangan penelitian menggunaan Rancangan Acak Kelompok (RAK) dengan 4 perlakuan dan 10 ulangan. Pengelompokan dilakukan berdasarkan waktu penampungan yang berbeda. Sedangkan perlakuan terdiri dari: $\mathrm{P0}(\mathrm{kontrol})=$ Pengencer CEP-3 $+20 \%$ kuning telur. $\mathrm{P} 1=$ Pengencer air kelapa $+20 \%$ kuning telur. $\mathrm{P} 2=$ Pengencer air kelapa $+20 \%$ kuning telur $+0,4 \%$ putih telur + fruktosa 1 $\mathrm{mg} / \mathrm{ml}$. P3 $=$ Pengencer air kelapa $+20 \%$ kuning telur $+0,4 \%$ putih telur + fruktosa $2 \mathrm{mg} / \mathrm{ml}$.

\section{Parameter yang diamati:}

Parameter kualitas semen sebelum diencerkan meliputi motilitas massa, motilitas individu, viabilitas, abnormalitas, konsentrasi, status akrosom. Sedangkan parameter kualitas semen cair diamati dalam penelitian ini meliputi, motilitas spermatozoa dan status akrosom spermatozoa.

\section{Pengamatan motilitas spermatozoa}

Gerak individu spermatozoa diamati menggunakan mikroskop cahaya dengan perbesaran 400 kali, kemudian dilakukan pengamatan spermatozoa yang bergerak secara progresif (Garner and Hafez, 2008).

\section{Pengamatan viabilitas spermatozoa}

Viabilitas spermatozoa dinyatakan dalam persentase jumlah spermatozoa yang hidup dihitung dari 200 pengamatan spermatozoa dengan menggunakan mikroskop cahaya perbesaran 400 kali. Sebelum diamati dilakukan pewarnaan eosin-negrosin. Spermatozoa yang mati akan menyerap warna eosin sehingga akan berwarna merah sedangkan spermatozoa yang masih hidup berwarna transparan (Susilawati, 2011).

\section{Pengamatan abnormalitas spermatozoa}

Perhitungan abnormalitas spermatozoa dilakukan dengan cara membuat preparat ulas dengan pewarnaan eorin-negrosin terlebih dahulu kemudian dilakukan pengamatan menggunakan mikroskop dengan perbesaran 400 kali. Spermatozoa abnormal bisa dilihat dari bentuk morfologi pada bagian kepala, leher dan ekor (Susilawati, 2013).

\section{Pengamatan status akrosom (CTC)}

Metode pemeriksaan status akrosom dengan pewarnaan Chlortetracycline (CTC) yang digunakan dalam pemeriksaan status akrosom dengan cara yaitu $45 \mu$ l semen dimasukkan dalam ependrof kapasitas $1,5 \mathrm{ml}$ yang ditutup dengan aluminiumfoil, tambahkan $45 \mu$ l larutan pewarna CTC dan goyang - goyang selama 1 - 3 menit, tambahkan $8 \mu$ l CTC Fixative dan goyang - goyang selama 1 menit. Larutan tersebut diambil $10 \mu \mathrm{l}$ dan ditempatkan pada gelas objek kemudian ditambahkan 10 $\mu \mathrm{l}$ 1,4-diazabicyclooctane (DABCO) dan dicampur secara hati-hati, kemudian ditutup dengan cover glass. Selanjutnya ditutup dengan kertas tisu yang tebal dan ditekan secara hati-hati, tepi cover glass ditutup dengan cutex (cat kuku) untuk melindungi dari kekeringan (Morado et al., 2015). 
HASIL DAN PEMBAHASAN Kualitas semen sapi PO

Pemeriksaan semen sapi PO sebelum diencerkan meliputi pemeriksaan makroskopis yang terdiri dari volume, $\mathrm{pH}$, warna, dan konsistensi spermatozoa.
Kemudian dilanjutkan dengan pemeriksaan mikroskopis yang meliputi motilitas massa, motilitas individu, viabilitas, abnormalitas, konsentrasi, status akrosom. Rataan dan simpangan baku kualitas semen sapi PO yang dinilai dapat dilihat pada Tabel 1.

Tabel 1. Rata-rata kualitas semen sapi PO yang digunakan dalam penelitian

\begin{tabular}{lc}
\hline Parameter & Rata-rata \pm sd \\
\hline Makroskopis & \\
Volume per ejakulat (ml) & $4,00 \pm 1,22$ \\
Warna & Putih - krem \\
pH & $6,48 \pm 0,11$ \\
Konsistensi & Sedang - kental \\
\hline Mikroskopis & ++ \\
Motilitas Massa & $72,00 \pm 2,74$ \\
Motilitas Individu (\%) & $92,20 \pm 2,32$ \\
Viabilitas (\%) & $2,59 \pm 0,67$ \\
Abnormalitas (\%) & $1208,00 \pm 179,78$ \\
Konsentrasi (juta/ml) & $86,40 \pm 1,97$ \\
Spermatozoa Belum Kapasitasi (\%) & $9,41 \pm 1,35$ \\
Spermatozoa Terkapasitasi (\%) & $4,19 \pm 1,02$ \\
Spermatozoa Telah Reaksi Akrosom (\%) & \\
\hline
\end{tabular}

Rata-rata hasil pengamatan volume semen dari sapi PO yang digunakan untuk penelitian adalah 4,00 $\pm 1,22 \mathrm{ml}$. Hasil tersebut termasuk rendah jika dibandingkan dengan pernyataan Garner and $\mathrm{Hafez}$ (2008) bahwa volume semen sapi hasil penampungan berkisar antara 5-8 $\mathrm{ml}$. Warna semen sapi PO yang didapatkan dalam penelitian adalah putih hingga krem. Susilawati (2011) menjelaskan bahwa semen sapi pada umumnya berwarna putih kekuning-kuningan atau hampir seputih susu dikarenakan karena adanya riboflavin di dalam semen. Adapun $\mathrm{pH}$ semen ratarata $6,48 \pm 0,11$. Hasil tersebut memperlihatkan bahwa $\mathrm{pH}$ semen yang digunakan untuk penelitian adalah normal. Ax et al. (2008) menjelaskan bahwa $\mathrm{pH}$ semen sapi berkisar antara 6,4 sampai 7,8.

Sedangkan pemeriksaan mikroskopis meliputi motilitas massa, motilitas individu, viabilitas, abnormalitas, konsentrasi, status akrosom. Rata-rata persentase motilitas massa semen sapi PO yang digunakan untuk penelitian adalah $2+$. Per- syaratan motilitas massa agar semen dapat diproses minimal 2+ (Ducha dkk., 2013). Rataan motilitas individu semen segar sapi PO yang digunakan adalah $72,00 \pm 2,74 \%$. Muhammad dkk. (2016) menyatakan bahwa syarat minimal nialai motilitas semen untuk diencerkan adalah $70 \%$. Nilai konsentrasi spermatozoa semen sapi PO yang digunakan adalah 1208,00 $\pm 179,78$ juta/ml. Garner and Hafez (2008) bahwa konsentrasi semen sapi bervariasi dari 1.000-1.800 juta spermatozoa setiap mililiter atau 800-2.000 juta spermatozoa setiap mililiter.

Rata-rata viabilitas spermatozoa sapi PO yang digunakan untuk penelitian adalah $92,20 \pm 2,32 \%$. Hal tersebut memiliki arti bahwa semen sapi PO yang digunakan dalam penelitian termasuk memenuhi syarat untuk digunakan. Ducha dkk., (2013) yang menyatakan bahwa semen yang akan diencerkan paling tidak minimal jumlah spermatozoa yang hidup $70 \%$. Rata-rata persentase abnormalitas semen sapi PO yang digunakan untuk penelitian adalah 
$2,59 \pm 0,67 \%$. Angka tersebut menunjukkan bahwa spermatozoa yang memiliki morfologi normal adalah 97,41\%. Itu artinya persentase normalitas semen sapi PO yang digunakan memiliki kategori yang baik, sebagaimana dijelaskan oleh Ismaya (2014) bahwa semen termasuk jelek dan daya fertilisasinya rendah jika persentase abnormalitasnya lebih dari $20 \%$.

\section{Motilitas semen cair berbagai perlakuan}

Motilitas adalah paremeter penting dalam kegiatan pengenceran semen untuk program inseminasi buatan. Rata-rata dan simpang baku motilitas semen cair sapi PO dengan berbagai perlakuan pengencer dasar air kelapa ditunjukkan pada Tabel 2.

Tabel 2. Rata-rata motilitas spermatozoa sapi PO selama penyimpanan suhu $2-5{ }^{\circ} \mathrm{C}$

\begin{tabular}{|c|c|c|c|c|c|c|c|c|c|}
\hline \multirow{2}{*}{ PERLAKUAN } & \multicolumn{9}{|c|}{ Rata-rata motilitas selama penyimpanan $(\%) \pm$ Simpang baku } \\
\hline & $\mathrm{H} 1$ & $\mathrm{H} 2$ & H3 & $\mathrm{H} 4$ & H5 & H6 & $\mathrm{H} 7$ & $\mathrm{H} 8$ & H9 \\
\hline P0 (CEP-3+ KT 20\%) & $\begin{array}{c}71,0 \\
\pm \\
2,1\end{array}$ & $\begin{array}{c}70,0 \\
\pm \\
0,0\end{array}$ & $\begin{array}{c}69,5 \\
\pm \\
1,6\end{array}$ & $\begin{array}{c}68,0 \\
\pm \\
2,6\end{array}$ & $\begin{array}{c}64,0 \\
\pm \\
5,2^{\mathrm{b}}\end{array}$ & $\begin{array}{c}59,5 \\
\pm \\
6,4^{b}\end{array}$ & $\begin{array}{c}51,0 \\
\pm \\
7,4^{b}\end{array}$ & $\begin{array}{c}41,5 \\
\pm \\
7,5^{b}\end{array}$ & $\begin{array}{c}27,0 \\
\pm \\
11,1^{\mathrm{b}}\end{array}$ \\
\hline P1 (AK + KT20\%) & $\begin{array}{c}70,0 \\
\pm \\
0,0\end{array}$ & $\begin{array}{c}69,0 \\
\pm \\
2,1\end{array}$ & $\begin{array}{c}67,0 \\
\pm \\
3,5\end{array}$ & $\begin{array}{c}66,0 \\
\pm \\
3,9\end{array}$ & $\begin{array}{c}57,0 \\
\pm \\
9,5^{\mathrm{a}}\end{array}$ & $\begin{array}{c}37,0 \\
\pm \\
5,4^{\mathrm{a}}\end{array}$ & $\begin{array}{c}27,0 \\
\pm \\
9,5^{\mathrm{a}}\end{array}$ & $\begin{array}{c}6,0 \\
\pm \\
6,6^{\mathrm{a}}\end{array}$ & $\begin{array}{c}4,5 \\
\pm \\
6,0^{\mathrm{a}}\end{array}$ \\
\hline $\begin{array}{l}\mathrm{P} 2(\mathrm{AK}+\mathrm{KT} 20 \%+\mathrm{PT} \\
0,4 \%+\text { Fruk } 1 \mathrm{mg} / \mathrm{ml})\end{array}$ & $\begin{array}{c}70,5 \\
\pm \\
1,6\end{array}$ & $\begin{array}{c}69,5 \\
\pm \\
1,6\end{array}$ & $\begin{array}{c}67,0 \\
\pm \\
3,5\end{array}$ & $\begin{array}{c}66,0 \\
\pm \\
3,9\end{array}$ & $\begin{array}{c}58,5 \\
\pm \\
7,5^{\mathrm{a}}\end{array}$ & $\begin{array}{c}39,0 \\
\pm \\
3,9^{\text {a }}\end{array}$ & $\begin{array}{c}27,5 \\
\pm \\
7,2^{\mathrm{a}}\end{array}$ & $\begin{array}{c}6,5 \\
\pm \\
3,4^{\mathrm{a}}\end{array}$ & $\begin{array}{c}3,5 \\
\pm \\
3,4^{\mathrm{a}}\end{array}$ \\
\hline $\begin{array}{l}\mathrm{P} 3(\mathrm{AK}+\mathrm{KT} 20 \%+\mathrm{PT} \\
0,4 \%+\text { Fruk } 2 \mathrm{mg} / \mathrm{ml})\end{array}$ & $\begin{array}{c}71,0 \\
\pm \\
2,1\end{array}$ & $\begin{array}{c}68,5 \\
\pm \\
2,4\end{array}$ & $\begin{array}{c}67,0 \\
\pm \\
4,2 \\
\end{array}$ & $\begin{array}{c}65,5 \\
\pm \\
4,4 \\
\end{array}$ & $\begin{array}{c}57,5 \\
\pm \\
7,2^{\mathrm{a}} \\
\end{array}$ & $\begin{array}{l}37,5 \\
\pm \\
5,4^{\mathrm{a}}\end{array}$ & $\begin{array}{c}27,0 \\
\pm \\
8,2^{\mathrm{a}}\end{array}$ & $\begin{array}{c}6,0 \\
\pm \\
2,1^{\mathrm{a}} \\
\end{array}$ & $\begin{array}{c}3,5 \\
\pm \\
2,4^{\mathrm{a}}\end{array}$ \\
\hline
\end{tabular}

Keterangan: KT $=$ Kuning Telur; AK = Air Kelapa; PT $=$ Putih Telur; Fruk = Fruktosa; $\mathrm{H}=$ Hari Notasi yang berbeda menunjukkan perberbeda yang sangat nyata $(\mathrm{P}<0,01)$

Hasil analisis ragam menunjukkan bahwa perlakuan berbagai pengencer dasar air kelapa berpengaruh sangat nyata $(\mathrm{P}<0.01)$ terhadap persentase motilitas spermatozoa pada hari penyimpanan ke-5 sampai ke-9. Hasil Uji Jarak Berganda Duncan menunjukkan bahwa perlakuan pengencer CEP-3 (P0) berbeda sangat nyata terhadap perlakuan pengencer berbahan dasar air kelapa (P1, P2, dan P3). Namun apabila perbandingan dilakukan hanya antar perlakuan pengencer berbahan dasar kelapa yaitu pada P1, P2 dan P3 pada hari peyimpanan ke5 sampai ke-6 tidak menunjukkan adanya perbedaan yang nyata antar sesama perlakukan air kelapa dengan formulasi yang berbeda tersebut.
Hasil uji Chi square terhadap motilitas spermatoza pada penyimpana hari ke-5 menunjukkan sesuai dengan nilai harapan dan nilai SNI yaitu diatas $40 \%$, sedangkan pada penyimpanan hari ke-6 menunjukkan nilai yang berbeda dengan nilai harapan maupun SNI. Penelitian ini menunjukkan hasil yang lebih tinggi dibandingkan dengan penelitian Aziz dkk. (2018) yang melaporkan bahwa pengecer air kelapa mampu menjaga motilitas spermatoza kambing boer hingga penyimpanan hari ke dua.

Antar perlakuan penambahan fruktosa pada pengencer air kelapa (P1, P2, P3) dengan proporsi yang berbeda menunjukkan hasil yang tidak berbeda nyata. Sper- 
matozoa sapi PO dalam mempertahankan hidup membutuhkan energi berupa Adenosine Triphosphate (ATP) yang didapatkan dari proses anabolisme sumber energi. Secara alami didalam plasma semen dan air kelapa terdapat sumber energi berupa fruktosa. Sehingga jika selama peyimpanan hingga hari ke 6 kebutuhan sumber energi spermatozoa sudah terpenuhi dari plasma semen dan air kepala maka penambahan fruktosa tidak akan memberikan pengaruh yang nyata terhadap motilitas spermatozoa. Susilawati (2011) menyatakan bahwa fruktosa adalah gula dasar dari seminal. Fruktosa merupakan sumber energi yang baik bagi spermatozoa karena jalur metobolisme yang lebih pendek yaitu me- lalui proses fruktoliasis dibandingan dengan glikolisis yang lebih panjang.

\section{Status akrosom spermatozoa}

Pemeriksaan status akrosom spermatozoa meliputi persentase spermatozoa yang belum mengalami kapasitasi, persentase spermatozoa yang sudah kapasitasi dan persentase spermatozoa yang sudah mengalami rekasi akrosom. Pemeriksaan status akrosom dapat menggunakan pewarnaan Chlortetracycline (CTC). Kondisi status akrosom pada spermatozoa mempengaruhi peredaran kalsium pada sel spermatozoa.

Rata-rata spermatozoa yang belum mengalami kapasitasi pada kondisi belum diencerkan, setelah penyimpanan hari ke-1 dan ke-5 ditinjukkan pada Tabel 3.

Tabel 3. Rata-rata spermatozoa belum kapasitasi

\begin{tabular}{cccc}
\hline \multirow{2}{*}{ P } & \multicolumn{3}{c}{ Rata-rata spermatozoa belum kapasitasi (\%) \pm Simpang baku } \\
\cline { 2 - 4 } & Segar & H1 & H5 \\
P0 & $86,4 \pm 2,0$ & $84,6 \pm 0,9$ & $67,6 \pm 0,6^{\mathrm{b}}$ \\
P1 & $86,4 \pm 2,0$ & $84,2 \pm 0,9$ & $64,7 \pm 0,6^{\mathrm{a}}$ \\
P2 & $86,4 \pm 2,0$ & $84,2 \pm 1,0$ & $66,1 \pm 0,7^{\mathrm{a}}$ \\
P3 & $86,4 \pm 2,0$ & $84,0 \pm 1,2$ & $65,6 \pm 0,5^{\mathrm{a}}$ \\
\hline
\end{tabular}

Keterangan: $\mathrm{P}=$ Perlakuan, $\mathrm{H}=$ Hari penyimpanan. Notasi yang berbeda menunjukkan perberbedaan yang sangat nyata $(\mathrm{P}<0,01)$

Hasil analisis ragam menunjukkan bahwa perlakuan berbagai pengencer dasar air kelapa berpengaruh sangat nyata $(\mathrm{P}<0.01)$ terhadap persentase spermatozoa belum kapasitasi pada hari penyimpanan ke-5. Hasil Uji Jarak Berganda Duncan menunjukkan bahwa perlakuan pengencer CEP-3 (P0) berbeda sangat nyata terhadap perlakuan pengencer berbahan dasar air kelapa (P1, P2, dan P3). Namun apabila perbandingan dilakukan hanya antar perlakuan pengencer berbahan dasar kelapa yaitu pada P1, P2 dan P3 pada hari peyimpanan ke5 tidak menunjukkan adanya perbedaan yang nyata antar sesama perlakukan air kelapa dengan formulasi yang berbeda tersebut.
Spermatozoa dapat mempertahankan kondisi sehingga belum terkapasitasi sangat dipengaruhi oleh kolesterol membran. Moore et al. (2005) melaporkan terjadi penurunan yang signifikan pada kolesterol membran spermatozoa setelah penurunan suhu yang sangat drastis. Kolesterol pada membran dapat berfungsi sebagai agen kapasitasi, jumlah dan distribusi kolesterol pada membran mengindikasikan tahapan kapasitasi.

Rata-rata spermatozoa yang telah mengalami reaksi akrosom pada kondisi segar, setelah penyimpanan hari ke-1 dan ke-5 ditinjukkan pada Tabel 4. 
Tabel 4. Rata - rata spermatozoa telah reaksi akrosom

\begin{tabular}{cccc}
\hline \multirow{2}{*}{$\mathrm{P}$} & \multicolumn{4}{c}{ Rata-rata spermatozoa belum kapasitasi (\%) \pm Simpang baku } \\
\cline { 2 - 4 } & Segar & H1 & H5 \\
\hline P0 & $4,2 \pm 1,0$ & $4,8 \pm 0,3$ & $11,3 \pm 0,5$ \\
P1 & $4,2 \pm 1,0$ & $5,5 \pm 0,2$ & $12,1 \pm 0,4$ \\
P2 & $4,2 \pm 1,0$ & $5,4 \pm 0,6$ & $11,9 \pm 0,5$ \\
P3 & $4,2 \pm 1,0$ & $5,3 \pm 0,9$ & $12,2 \pm 0,7$ \\
\hline
\end{tabular}

Keterangan : $\mathrm{P}=$ Pelakuan, $\mathrm{H}=$ Hari penyimpanan.

Tidak berbeda nyata $(\mathrm{P}>0,05)$

Hasil analisis ragam menunjukkan bahwa perlakuan berbagai pengencer dasar air kelapa tidak memberikan pengaruh nyata $(\mathrm{P}>0.05)$ terhadap persentase spermatozoa telah reaksi akrosom pada hari penyimpanan ke-1 dan hari ke-5. Meskipun hasil analisis ragam tidak menunjukkan perbedaan yang nyata, namun nilai rata-rata spermatozoa yang telah mengalami reaksi akrosom pada pengencer P0 (CEP-3) cenderung lebih baik dari pada ketiga perlakuan yang lainnya.

Persentase keutuhan akrosom tersebut mengindikasikan bahwa tidak terdapat kerusakan spermatozoa yang dapat menurunkan kemampuan fertilisasinya. Menurut Hernandez et al. (2012) spermatozoa kehilangan kemampuan fertilisasi apabila diperoleh kerusakan akrosom melebihi $50 \%$. Kerusakan akrosom spermatozoa tersebut berkaitan dengan fungsi membran sebagai pelindung akrosom spermatozoa. Kolesterol merupakan salah satu komponen penyusun membran spermatozoa dan juga berfungsi memberikan sifat fluiditas pada membran sehingga tidak mudah rusak. Kandungan kolesterol tinggi pada membran akan membuat membran semakin bersifat lentur sebaliknya semakin rendah kandungan kolesterol pada membran akan menyebabkan spermatozoa semakin mudah mengalami kerusakan.

\section{KESIMPULAN}

1) Pengencer berbasis air kelapa dengan berbagai formulasi mampu memper- tahankan motilitas diatas $40 \%$ hingga hari ke-5.

2) Perbedaan formulasi pada pengencer berbasis air kelapa tidak memberikan pengaruh terhadap motilitas, dan status akrosom sepermatozoa selama penyimpanan pada suhu $2-5^{\circ} \mathrm{C}$.

\section{UCAPAN TERIMA KASIH :}

Kemenristek DIKTI yang telah memberikan dana penelitian dengan skema PUPTN dan Lembaga Pengelolah Dana Pendidikan (LPDP) melalui program BPI. Terima kasih juga kepada Loka Penelitian Sapi Potong Grati yang menyediakan tempat penelitian.

\section{DAFTAR PUSTAKA}

Adnani, Luh P. D. H, W. Bebas, M. K. Budiasa. 2012. Penambahan bovine serum albumin pada pengencer kuning telur terhadap motilitas dan daya hidup spermatozoa anjing. Indonesia Medicus Veterinus, 1(4), 519-529.

Audia, R. P., M. A. Salim, N. Isnaini dan T. Susilawati. 2017. Pengaruh perbedaan kematangan air kelapa hijau sebagai bahan pengencer yang ditambah $10 \%$ kuning telur terhadap kualitas semen cair kambing Boer. Jurnal Ternak Tropika, 18(1), 58-68.

Ax, R., M. Dally, B. Didion, R. Lenz, C. Love, D. Varner, Hafez, and M. Bellin. 2008. Semen Evaluation. In Re- 
production in Farm Animal $\left(7^{\text {th }}\right.$ edition). Edited by Hafez, E.S.E. Co. Director. Reproductive Health Kiawah Island. South Carolina. USA: 365-370.

Aziz, A. F., M. A. Salim, N. Isnaini, A.P. A. Yekti, dan T. Susilawati. 2018. Pengaruh pengencer air kelapa tua yang berbeda varietas terhadap kualitas semen cair kambing Boer pada penyimpanan 3-5 ${ }^{\circ} \mathrm{C}$. Jurnal IlmuIlmu Peternakan, 28(2), 112 - 120.

Ducha, N., T. Susilawati, Aulanni'am, dan S. Wahjuningsih. 2013. Motilitas dan viabilitas spermatozoa sapi Limousin selama penyimpanan pada refrigerator dalam pengencer CEP-2 dengan suplementasi kuning telur. Jurnal Kedokteran Hewan, 7(1), 5-8.

Garner, D.L. and E.S.E. Hafez. 2008. Spermatozoa and Seminal Plasma. In Reproduction in Farm Animals $\left(7^{\text {th }}\right.$ edition). Edited by E.S.E Hafez and B. Hafez. 2008. Lippincott \& Williams. Baltimore, Marryland. USA: 96-109.

Hernandez, P.J.E., Fernandez R.F., Rodriguez S.J.L, Soto M.Y.G., Verona J.E.H., Garcia R.A.D. 2012. Postthaw acrosomal viability and reaction in sperm obtained from equine epididymis tail. Rev Salud Anim, 34(2), 84-88.

Ismaya. 2014. Bioteknologi Inseminasi Buatan pada Sapi dan Kerbau. Gadjah Mada University Press. Yogyakarta. ISBN 979-420-848-5.

Moore AI, Squires EL, Graham JK. 2005. Adding cholesterol to the stallion sperm plasma membrane improve cryosurvival. Cryobiology, 51(3), 241-249.
Morado, S., Pereyra, V., Breininger, E., Sara, R. and Cetica, P. 2015. Study of sperm evaluation parameters to estimate cryopreserved bovine semen fertility. Austin Journal of Veterinary Science \& Animal Husbandry, 2(1), 1005.

Mugiyati, Salin M. A., N. Isnaini, dan T. Susilawati. 2017. Pengaruh air kelapa merah yang muda dan tua sebagai pengencer terhadap kualitas semen kambing Boer selama penyimpanan dingin. Jurnal Ternak Tropika, 18(1), 20-26.

Muhammad, D., T. Susilawati, S. Wahjuningsih. 2016. Pengaruh penggunaan CEP-2 dengan suplementasi kuning telur terhadap kualitas spermatozoa sapi FH (Frisian Holstein) kualitas rendah selama penyimpanan suhu 4$5^{\circ}$ C. Jurnal Ternak Tropika, 17(1), 66-76.

Susilawati, T. 2011. Spermatology. Universitas Brawijaya (UB) Press. Malang. ISBN 978-602-8960-04-5.

Susilawati, T. 2013. Pedoman Inseminasi Buatan pada Ternak. Universitas Brawijaya (UB) Press. Malang. ISBN 978-602-203-458-2.

Susilawati, T., D. Ratnawati, N. Isnaini, Kuswati and A. P. A. Yekti. 2018. Character of liquid semen motility in various diluents on Balinese cattle during cold storage. Asian Journal of Microbiology, Biotechnology \& Environmental Sciences, 20(1), 166172.

Vigliar R., V. L. Sdepanian, U. FagundesNeto. 2006. Biochemical profile of coconut water from coconut palms planted in an Inland Region. Jornal de Pediatria, 82(4), 308-312. 